\title{
Nesiritide not verified
}

How can a drug, that is associated with higher rates of both renal dysfunction and death than placebo - and costs 50 times as much as standard therapies and for which there are no meaningful data on relevant clinical endpoints - be given to more than 600000 patients and be promoted throughout the United States for serial outpatient use, an indication not listed on label.

Nadpis a úvodní odstavec jsem si vypůjčil od prof. Erica J. Topola. Tento článek publikoval v New England Journal of Medicine 14. června 2005 a podivoval se nad faktem, že americký Úřad pro kontrolu potravin a léčiv (Food and Drug Administration - FDA) schválil v roce 2001 nesiritid (rekombinantní BNP) jako lék pro akutní srdeční selhání (resp. na snížení tlaku v zaklínění) a tento lék se začal v USA široce užívat. Přibližně ve stejné době jsem dostal od prof. Roberta M. Califfa nabídku stát se národním koordinátorem a členem steering committee studie ASCEND-HF (Acute Study of Clinical Effectiveness of Nesiritide in Decompensated Heart Failure). Moje první funkce - národní koordinátor - skončila poměrně brzy, protože Státní ústav pro kontrolu léčiv (SÚKL) studii neschválil jako neetickou, a studie ASCEND tedy v České republice ani nezačala. Druhá funkce - člen steering committee - mi ale zůstala, a tak jsem se pět let pravidelně zúčastňoval během amerických i evropských kardiologických kongresů zasedání steering committee a sledoval, jak se studie vyvíjí. Během této doby jsem zaznamenal několik zajímavých poznatků. Především data safety monitoring committee opakovaně vyhodnocovala renální funkce a vždy doporučila ve studii pokračovat, protože nenalezla zhoršení renálních funkcí. Druhou zajímavostí bylo, že po krátké době od začátku studie odstoupily ze studie Německo a Švédsko (obě země zařadily pět pacientů), protože podobně jako SÚKL označily studii jako neetickou. V náboru se ale pokračovalo a na rozdíl od většiny jiných studií byla většina nemocných (45\%) randomizována v USA a Kanadě, protože $\mathrm{v}$ těchto zemích měla studie velkou podporu sponzora i národních autorit.

Třetí zajímavostí bylo sledování délky hospitalizace a mortality pacientů podle jednotlivých regionů, bez ohledu na to, ve které větvi jsou zařazeni. Spojené státy americké měly nejkratší dobu hospitalizace - čtyři dny, nejnižší nemocniční mortalitu - 4\%, ale nejvyšší počet rehospitalizací a úmrtí do 30 dnů - 12,7 \%, což vyvolalo závěr, že méně je někdy hưře a že krátká doba hospitalizace v USA nemá důvody medicínské, ale ekonomické a že snaha dostat nemocného co nejdříve $\mathrm{z}$ nemocničního lůžka domů je bohužel zaplacena vyšší úmrtností. Střední a východní Evropa měla délku hospitalizace sedm dní a 30denní rehospitalizace a úmrtí 5,1\%. Rozdíl mezi USA a střední a východní Evropou byl významný především pro 30denní rehospitalizace ( $9,5 \%$ vs. 2,0 \%) a střední a východní Evropa měla jednoznačně nejdelší dobu první hospitalizace, ale nejnižší 30denní mortalitu $(3,1 \%)$ i rehospitalizace $(2,0 \%)$.

$\mathrm{Na}$ kongresu American Heart Association v Chicagu v listopadu 2010 byly prezentovány konečné výsledky studie ASCEND-HF doktorem Adrianem F. Hernandesem, tzv. diskutérem byl prof. E. Braunwald.

Studie ASCEND-HF zařadila 7007 nemocných s akutním srdečním selháním, kteří museli být randomizováni do 24 hodin od vzniku příznaků a ke standardní léčbě byl přidán nesiritid nebo placebo na dobu 24 až 168 hodin. Primárním cílovým ukazatelem bylo posouzení dušnosti na sedmistupňové škále za 6 a 24 hodin a 30denní mortality a rehospitalizace pro srdeční selhání. Základní charakteristiku pacientů uvádí tabulka 1 .

Hlavní výsledek - změnu dušnosti po 6 a 24 hodinách popisuje tabulka 2.

Co se týče primárního cílového ukazatele - změny dušnosti, bylo dosaženo pozitivního výsledku, protože statisticky významně více nemocných se zlepšilo při podávání nesiritidu než při podávání placeba.

Druhý primární cílový ukazatel - 30denní rehospitalizace a mortalitu - ukazuje tabulka 3.

Třicetidenní mortalita a rehospitalizace ukazují trend ve prospěch nesiritidu, který však nedosáhl statistické významnosti.

Velká pozornost byla věnována bezpečnosti podávání nesiritidu, především výskytu zhoršení renálních funkcí a hypotenzi (tabulka 4).

Tabulka 1 Základní charakteristika nemocných ve studii ASCEND-HF

\begin{tabular}{lll}
\hline Parametr & $\begin{array}{l}\text { Placebo } \\
(\mathbf{n}=3511)\end{array}$ & $\begin{array}{l}\text { Nesiritid } \\
(\mathbf{n}=3496)\end{array}$ \\
\hline Věk & $67(56,76)$ & $67(56,76)$ \\
\hline Pohlaví mužské (\%) & 65,1 & 66,6 \\
\hline Systolický krevní tlak (mm Hg) & $124(110,140)$ & $123(110,140)$ \\
\hline Diastolický krevní tlak (mm Hg) & $74(67,83)$ & $74(66,84)$ \\
\hline Tepová frekvence & $82(72,95)$ & $82(72,95)$ \\
\hline Dechová frekvence & $24(21,26)$ & $23(21,26)$ \\
\hline BNP (pg/ml) (medián) & 988,5 & 1000 \\
\hline NT-proBNP (pg/ml) (medián) & 4445 & 4509 \\
\hline Ejekční frakce < 40 \% (\%) & 79,5 & 80,8 \\
\hline
\end{tabular}

Tabulka 2 Změna dušnosti ve studii ASCEND-HF

\begin{tabular}{|c|c|c|c|}
\hline & Placebo n (\%) & Nesiritid n (\%) & $p$ \\
\hline \multicolumn{4}{|l|}{6 hodin } \\
\hline Výrazně zlepšen & $460(13,4)$ & $513(15,0)$ & \multirow[t]{7}{*}{0,03} \\
\hline Zlepšen & $989(28,7)$ & $1007(29,5)$ & \\
\hline Mírně zlepšen & $1174(34,1)$ & $119(32,8)$ & \\
\hline Beze změny & $748(21,7)$ & $692(20,3)$ & \\
\hline Mírně zhoršen & $40(1,2)$ & $39(1,1)$ & \\
\hline Zhoršen & $13(0,4)$ & $12(0,4)$ & \\
\hline Výrazně zhoršen & $20(0,6)$ & $34(1,0)$ & \\
\hline \multicolumn{4}{|l|}{24 hodin } \\
\hline Výrazně zlepšen & $935(27,5)$ & $1025(30,4)$ & \multirow[t]{7}{*}{0,007} \\
\hline Zlepšen & $1313(38,6)$ & $1274(37,8)$ & \\
\hline Mírně zlepšen & $751(22,1)$ & $716(21,2)$ & \\
\hline Beze změny & $323(9,5)$ & $291(8,6)$ & \\
\hline Mírně zhoršen & $16(1,1)$ & $27(0,8)$ & \\
\hline Zhoršen & $15(0,4)$ & $7(0,2)$ & \\
\hline Výrazně zhoršen & $25(0,7)$ & $31(0,9)$ & \\
\hline
\end{tabular}


Tabulka 3 Třicetidenní mortalita a rehospitalizace

\begin{tabular}{llll}
\hline & $\begin{array}{l}\text { Placebo } \\
\mathbf{n}(\%)\end{array}$ & $\begin{array}{l}\text { Nesiritid } \\
\text { n (\%) }\end{array}$ & p \\
\hline $\begin{array}{llll}\text { 30denní mortalita a } \\
\text { rehospitalizace }\end{array}$ & $345(10,1)$ & $321(9,4)$ & \\
\cline { 1 - 2 } 30denní mortalita & $141(4,0)$ & $126(3,6)$ & \\
\hline 30denní rehospitalizace & $208(6,1)$ & $204(6,0)$ & \\
\hline
\end{tabular}

Tabulka 4 Zhoršení renálních funkcí a hypotenze ve studii ASCEND-HF

\begin{tabular}{|c|c|c|c|}
\hline & $\begin{array}{l}\text { Placebo } \\
\text { n (\%) }\end{array}$ & $\begin{array}{l}\text { Nesiritid } \\
\mathrm{n}(\%)\end{array}$ & $p$ \\
\hline $\begin{array}{l}\text { Zhoršení renálních } \\
\text { funkcí o > } 25 \%\end{array}$ & $968(29,5)$ & $1032(31,4)$ & 0,109 \\
\hline $\begin{array}{l}\text { Zhoršení renálních } \\
\text { funkcí o > } 25 \% \\
\text { u nemocných s GFR } \\
<60 \mathrm{ml} / \mathrm{min} / 1,73 \mathrm{~m}^{2}\end{array}$ & $449(26,2)$ & $484(28,2)$ & 0,164 \\
\hline Hypotenze & $538(15,3)$ & $930(26,6)$ & $<0,0001$ \\
\hline $\begin{array}{l}\text { Symptomatická } \\
\text { hypotenze }\end{array}$ & $141(4,0)$ & $250(7,1)$ & $<0,0001$ \\
\hline
\end{tabular}

Z tabulky 4 je patrno, že nebyl potvrzen negativní vliv nesiritidu na renální funkce a že z tohoto pohledu byl nesiritid bezpečný, a to dokonce i u nemocných, u nichž byla na počátku glomerulární filtrace snížena. Na druhé straně výskyt hypotenze, a to jak symptomatické, tak asymptomatické, byl po nesiritidu téměř dvojnásobný.
Z dalších nažádoucích závažných př́ihod je třeba zmínit dvojnásobný výskyt reinfarktu při léčbě nesiritidem (14 vs. 6), který ale nedosáhl statistické významnosti.

Velkou snahou bylo definovat subpopulaci nemocných, kteři by mohli mít prospěch z léčby, nebyl však nalezen žádný podstatný parametr, který by definoval nemocné vhodné pro léčbu nesiritidem. Tuto snahu nalézt subpopulace vhodných nemocných vtipně parafrázoval R. Califf, který řekl, že pro nesiritid je vhodný pacient s nízkou ejekční frakcí i krevním tlakem, který nebere diuretika a nedostane je ani při hospitalizaci, je ve věku 64-75 let a do šesti hodin je u něj výrazná úleva - pak bude mít velkou pravděpodobnost, že nezemře.

Steering committee poté navrhla tyto závěry:

> nesiritid nesnižuje 30denní rehospitalizace,

nesiritid nesnižuje 30denní mortalitu,

nesiritid zlepšuje dušnost po 6 a 24 hodinách,

nesiritid nezhoršuje renální funkce do 30 dní.

Nesiritid je tedy lék bezpečný, ale bez prokázaného klinického účinku na rehospitalizace a mortalitu. Léčba akutního srdečního selhání tak zůstává nadále empirickou, bez dat založených na vědeckých důkazech a s nutností věnovat se nejen sledovat nejen tyto základní ukazatele, ale i ukazatele vedlejší, jako je úleva nemocného, snížení symptomatologie atd. Výsledky studie ASCEND-HF potvrzují nutnost klinického myšlení u akutního srdečního selhání a zařazují nesiritid k lékům, jako je levosimendan či tolvaptan, kde ošetřující lékař pozoruje klinické zlepšení při podávání daného léku, ale velké klinické studie (REVIVE, SURVIVE či EVEREST) nepotvrdily zlepšení prognózy - mortality a rehospitalizací.

Prof. MUDr. Jindr̈̈ch Špinar, CSC., FESC,

Interní kardiologická klinika, Fakultní nemocnice Brno,

e-mail:jspinar@fnbrno.cz 